\title{
Vivekananda, Sarah Farmer, and global spiritual transformations in the fin de siècle - CORRIGENDUM
}

\section{Ruth Harris}

https://doi.org/10.1017/S1740022819000020, Published by Cambridge University Press, 8 July 2019.

Keywords: anti-imperialism; Baha’i; Green Acre; Hindu Universalism; Sarah Farmer; Vivekananda; corrigendum

In the article 'Vivekananda, Sarah Farmer, and global spiritual transformations in the fin de siècle', ${ }^{1}$ Sophie-Jung Hyun Kim's name was incorrectly spelled on page 182 in footnote 19.

Sophie Kim Jung should read Sophie-Jung Hyun Kim.

\section{Reference}

${ }^{1}$ Ruth Harris, 'Vivekananda, Sarah Farmer, and global spiritual transformations in the fin de siècle', Journal of Global History, 14, 2, 2019, pp. 179-198. https://doi.org/10.1017/S1740022819000020

Cite this article: Harris R. 2019. Vivekananda, Sarah Farmer, and global spiritual transformations in the fin de siècle CORRIGENDUM. Journal of Global History 14: 475, doi:10.1017/S1740022819000135

(c) Cambridge University Press 2019. 